\title{
TRANSITION IN RURAL ECONOMY: AN EMPLOYMENT PERSPECTIVE
}

\author{
Mukesh Kumar* \\ Azeema Begam** \\ Nargis Noman ${ }^{* * *}$
}

\begin{abstract}
The process of transition in rural economy has been observed with the deepest and fastest structural transformation from farm to non-farm sector in Pakistan. The structure and composition of labour market is also undergoing such considerable changes due to increasing share of the non-farm sector. Given this insight, the study assesses the change in rural economy particularly relying on population and migration trend and employment transition. The descriptive analysis of the study reveals that there is declining trend in migration from rural to urban areas with a considerable transition in employment from farm to non-farm sectors. The factor analysis points out the fact that push incentives of the farm sector are stronger than the pull incentives of the nonfarm sector for the movement of labour away from the farm sector in Pakistan. Hence, an immense focus is required for the farm sector in the lieu of employment opportunity while creating more diversification in non-farm activities in rural areas. Thus, there is also a dire need to enhance occupational activities such as agro-based processing, new farming practices, livestock, small scale manufacturing, retail trade, construction etc. to enhance the earnings of labour in the rural economy.
\end{abstract}

Keywords: Rural; transition; employment; farm; non-farm

\section{Introduction}

Rural transition is considered as a proactive and positive change as it takes in to account the progress of rural economy through socio-economic developments ${ }^{1,2}$. Precisely, rural transition is a more dynamic procedure as it exhibits auspicious aftermaths for agriculture intensification, rural employment, farm income, household well-being, poverty, labour productivity etc ${ }^{3}$.

This work is Licensed under a Creative Commons Attribution-Non-Commercial 4.0 International License (c) () (9)

${ }^{*}$ Mukesh Kumar, Ph.D. Scholar, Department of Business Management, Institute of Business Management (IoBM), Korangi Creek, Karachi.

** Azeema Begam, Ph.D. Research Scholar, Department of Economics, University of Karachi, Karachi

*** Nargis Noman, Ph.D. Research Scholar, Applied Economics Research Centre (AERC), University of Karachi, Karachi.

${ }^{1}$ Ohlan, Ramphul. "Rural Transformation in India in the Decade of Miraculous Economic Growth." Journal of Land and Rural Studies 4, no. 2 (2016): 188-205.

${ }^{2}$ Wang, Yanfei, Yansui Liu, Yuheng Li, and Tingting Li. "The Spatio-Temporal Patterns of Urban-Rural Development Transformation in China Since 1990.” Habitat International 53 (2016): 178-187.

${ }^{3}$ Ravallion, Martin, and Gaurav Datt. "Why has Economic Growth Been More Pro-Poor in some States of India than Others?.” Journal of Development Economics 68, no. 2 (2002): 381-400. 
The idea of rural change stems from the theory of structural transformation which discusses the decline in reliance on agriculture or farm sector than the modern sectors (manufacturing and services sector). Conventionally, the growth of the farm sector and increase in labour productivity allows the farm labour to switch their jobs to non-farm sectors. In this regard, various changes in the economy are expected to be observed. These include migration of rural residents to urban clusters, city developments, rapid urbanization and transition in rural economy. Consequently, a structural change transforms the economy from dominated farm sector to the modern non-farm sectors ${ }^{4}$.

\section{Theoretical Framework: Linking Structural Transformation and Rural Economy}

The fast pace of economic development has been attributed to divergent elements that enhance the economic activity. Given this optimism, structural transformation is considered crucial to determine the path of economic development of an economy. This concept was initiated by the work of Fisher ${ }^{5}$, Clark $^{6}$, Kuznets ${ }^{7}$ and Chenery, Syrquin and Elkington ${ }^{8}$. These economists primarily depicted changes in the sectoral structure of an economy through the channels of productivity and employment. However, in contemporary era, the horizon of sectoral transformation is now more disaggregated capturing the dynamics of both rural and urban clusters. Further, keeping in view the traditional developing economies, rural areas have more plausible implications of the transition rather than the urban clusters. Therefore, the theoretical framework of the study in figure 1 links the structural transformation and rural economy in the context of employment.

Theoretically, transition of rural economy is classified into two phases. The first phase is discussed through the renowned theory of Unlimited Supply of Labour presented by Lewis". Moreover; the concept of "Dual Economy" also segregates the advanced industrial (capital-intensive) and traditional agricultural (labour intensive) economy ${ }^{10}$. Hence, the rural economy is further segregated into farm and non-farm sectors. Precisely, these schools of thought consider rural economy as a pool of surplus labour that can conveniently transferred to the modern or non-farm sector at low wages without decreasing the output. Thus, such amendments in rural economy would alter the employment prospects in favor of non-farm economy. Lewis ${ }^{11}$ disclosed that if process continues up to a certain point, there would be no surplus labour and the economy would achieve full employment level. The second phase of structural transition discusses the increase in employment share in the services sector where consumers prefer luxury

\footnotetext{
${ }^{4}$ Wiggins, Steve, Rachel Sabates-Wheeler, and Joseph Yaro. "Rural Transitions, Economies and Rural-Urban Links." (2018).

${ }^{5}$ Fisher, Allan GB. "Production, Primary, Secondary and Tertiary." Economic Record 15, no. 1 (1939): 24-38.

${ }^{6}$ Clark, John M. "Toward A Concept of Workable Competition." The American Economic Review (1940): 241-256.

7 Kuznets, Simon Smith. “Economic Growth of Nations.” (1971).

${ }^{8}$ Chenery, Hollis Burnley, Moises Syrquin, and Hazel Elkington. Patterns of Development, 1950-1970. Vol. 75. London: Oxford University Press, 1975.

9 Lewis, W. Arthur. "Economic Development with Unlimited Supplies of Labour.” The Manchester School 22, no. 2 (1954): 139-191.

10 Ibid.

${ }^{11}$ Ibid.
} 
goods and manufacturing sector requires more inputs and this would in turn enhance the employment and wages in the respective sector.

\section{Figure 1: Theoretical Framework}

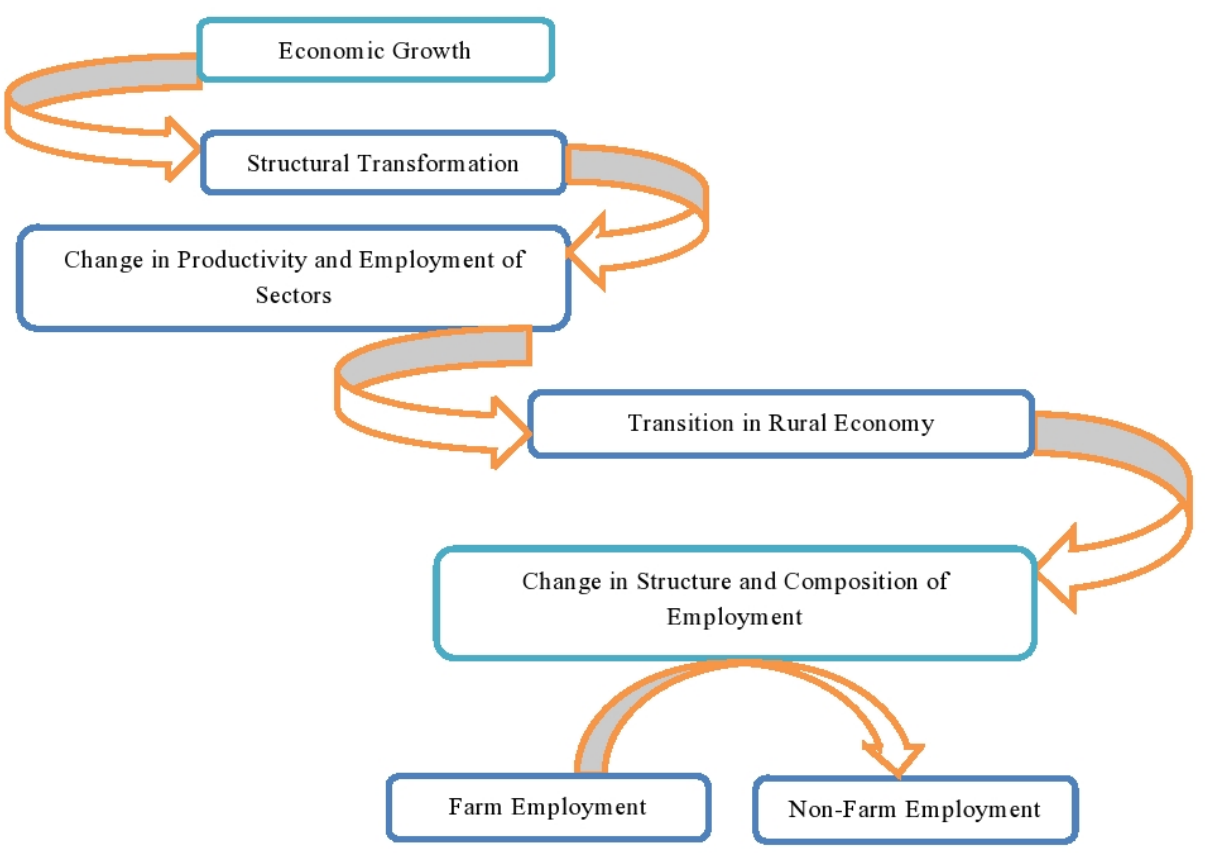

Given these theoretical aspirations, it is expected by various economists such as Fisher ${ }^{12}$; Clark ${ }^{13}$; Bamoul ${ }^{14}$ and Fuchs ${ }^{15}$; and Papola ${ }^{16}$ that this whole process alters the structure and composition of employment in the rural economy favoring the non-farm sector. Hence, the theoretical perspective of the study rotates around exploring the farm and non-farm employment sector of the rural economy given the prevailing transition in the Pakistan.

${ }^{12}$ Fisher, Allan GB. "Production, Primary, Secondary and Tertiary." Economic Record 15, no. 1 (1939): 2438.

${ }^{13}$ Clark, John M. "Toward a concept of workable competition.” The American Economic Review (1940): 241256.

${ }^{14}$ Baumol, W. J. "Macroeconomics of Unbalanced Growth: The Anatomy of Urban Crisis". The American Economic Review, 57(3), (1967): 415-426.

${ }^{15}$ Fuchs, Victor R. "The Service Economy”, (New York: NBER, 1968).

${ }^{16}$ Papola, "Emerging Structure of Indian Economy: Implications of Growing Inter-sectoral Imbalances", Presidential address of $88^{\text {th }}$ Conference of the Indian Economic Association, (Andhra University, Visakhapatnam, December 2005), 27-29. 


\section{Structural Transformation: Trends in Pakistan}

As it is mentioned earlier, the historic arrangement of structural transformation suggests a shift of income and employment from traditional sector to the advanced sectors. Despite the flagging economic scenario, the economy of Pakistan has also gone through the process of structural transformation. Predominantly, these changes have converted the farm structure of Pakistan to a more expanded economy of production and services i.e. non- farm sector ${ }^{17}$. This change can easily be verified through the data provided in table 1 that reveals the employment and income shares of the farm and non-farm sectors of Pakistan during given time period of 1980-2018.

Table 1: Employment and Income Shares of Farm and Non-Farm Sectors

\begin{tabular}{|c|c|c|c|c|c|c|c|c|c|}
\hline \multirow[b]{3}{*}{ Year } & \multicolumn{4}{|c|}{ Employment } & \multirow{3}{*}{$\begin{array}{c}\text { Transition } \\
\text { of } \\
\text { Labour }^{\text {ts }} \\
\end{array}$} & \multicolumn{4}{|l|}{ Income } \\
\hline & \multirow[b]{2}{*}{ Farm } & \multicolumn{3}{|l|}{ Non-Farm } & & \multirow[b]{2}{*}{ Farm } & \multicolumn{3}{|c|}{ Non-Farm } \\
\hline & & Industry & Services & Total & & & Industry & Services & Total \\
\hline 1980 & 52.72 & 10.16 & 37.12 & 47.28 & - & 30.82 & 22.6 & 46.57 & 69.17 \\
\hline 1985 & 50.56 & 19.44 & 30.01 & 49.45 & -4.09 & 28.53 & 22.47 & 48.99 & 71.46 \\
\hline 1990 & 47.45 & 19.00 & 33.53 & 52.53 & -6.15 & 25.66 & 25.76 & 48.57 & 74.33 \\
\hline 1995 & 46.79 & 17.71 & 35.51 & 53.22 & -1.39 & 26.13 & 24.76 & 50.06 & 74.82 \\
\hline 2000 & 48.42 & 17.33 & 34.25 & 51.58 & 3.48 & 25.92 & 23.32 & 50.74 & 74.06 \\
\hline 2005 & 43.05 & 19.63 & 37.32 & 56.95 & -11.09 & 21.46 & 27.10 & 51.43 & 78.53 \\
\hline 2010 & 44.96 & 20.88 & 34.96 & 55.84 & 4.43 & 24.29 & 20.58 & 55.13 & 75.71 \\
\hline $2015^{*}$ & 42.27 & 22.8 & 34.93 & 57.73 & -5.98 & 25.46 & 19.00 & 55.5 & 74.50 \\
\hline 2018 & 38.49 & 23.89 & 37.62 & 61.51 & -8.94 & 18.86 & 20.91 & 60.23 & 81.14 \\
\hline
\end{tabular}

The table 1 points out the prominent impact of structural change in favor of non-farm sector in terms of both income and employment share. The income compositions of farm and non-farm activities over the years show that the share of non-farm activity has persistently increased from 69.17 percent to 81.14 percent during the period of 1980 2018. However, the prominent growth in income of the non-farm sector over the years has been gradually transmuted to the employment of non-farm sector. The employment share of the non-farm sector has grown from 47.28 to 61.51 from 1980 to 2018.This slow movement is yet attributed to the continued dominance of the agriculture sector in employment of Pakistan. However, it is evident that there is an increasing trend of employment transition towards non-farm employment. This trend was found highest over the periods of 1985-90; 2000-05; and 2015-18 with 6.15, 11.09 and 8.94 percent respectively. These were much higher magnitudes of labour transition compared to the other time durations.

${ }^{17}$ Husain, Ishrat. "Pakistan's Growth Experience.” IBA Business Review 5, no. 2 (2010). 
Additionally, the employment showed a reverse trend towards farm sector with 3.4 percent increase in farm employment between 1994-95 and 1999-00. This trend was also observed during the period of 2005-10 with 4.43 percent of labour transition in favor of farm sector. This could be attributed to the significant progress observed during the period due to the fact that 12.81 million jobs were created during six years (200006). Meanwhile, out of total jobs 8.61 million were created in rural areas which constituted the 67.2 percent of the total job creation ${ }^{18}$. On the whole, the employment trend showed a surge in transition to the non-farm activities.

Considering the recent computed change between last three years (2015-18), it is observed that 8.94 percent of farm employments have been shifted to the non-farm sector during last three years. The computations of the table are thus providing an intuition that the economy of Pakistan will further witness the movement of workers away from the agricultural sector and meanwhile joining towards the non-agricultural sector. This trend is consistent with other global economies and also had definitely altered various parameters at both aggregate and disaggregates level.

The structural changes have the potential to further alter the composition of output, growth and employment in both rural and urban economies, precisely, in favor of urban clusters. This will in turn choke the productive resources while widening the income inequality between rural and urban areas ${ }^{19}$. Intuitively, this has also transformed the rural and urban economies of Pakistan and thus the labour market dynamics in respective economies. This has induced to observe the farm and non-farm sector of the rural economy to extract the cause and effect of this transition in rural areas of Pakistan.

\section{Rural Economy of Pakistan}

The traditional rural economy has always been associated with high unemployment rates, low employment opportunities, and low human capital of the farm sector ${ }^{20}$. In this regard, two possible explanations can be tested. First, the non-farm sector and specifically services sector have more potential to absorb the surplus labour from the farm sector ${ }^{21}$. Second, the informal sector of the labour market absorbs the substantial surplus labour that exists in agriculture and shift of labour has taken place from informal sector of agriculture to informal sector of the non-agricultural ${ }^{22}$

These arguments provide an instinct to observe the rural economy of Pakistan as it is generally mixed where population relies on its earnings from interdependent activities of agricultural and non-agricultural sectors. As per estimates based on the Labour Force Survey (LFS) for the year 2017-18, the magnitude of the labour force in Pakistan has

18 Pakistan Economic Survey, 2006-07

${ }^{19}$ Djanibekov, Nodir, Thomas Herzfeld, and Peter Weingarten. "Rural Areas in Transition: An Introduction." (2014): 125-126.

${ }^{20}$ Gill, Sucha Singh. "Agriculture, Crop Technology and Employment Generation in Punjab." Future of Agriculture in Punjab, Chandigarh: CRRID Publishers (2002).

${ }^{21}$ Mao, Rui, and Jianwei Xu. "Labor Market Dynamics and Structural Change: Evidence from China." China \& World Economy 23, no. 4 (2015): 60-83.

22 Behera, Deepak Kumar, and Mitali Tiwari. "Structural Transformation in India: An Econometric Investigation." Italian Economic J 56, no. 1 (2015): 1-18. 
increased from 61.04 million to 65.50 million from the year 2014-15 and 2017-18 respectively while the majority of the labour force (42.91 million) still works in rural clusters either in farm or non-farm sectors. This has in turn also transformed the rural economy over the years in terms of both employment and output, which is vital for the development and sustainability of the economy of Pakistan ${ }^{23}$. Meanwhile, the development of rural areas in Pakistan is playing its significant part to develop non-farm sector. Thus, the non-farm sector is set to be the mainstay of rural progress of any developing economy which in turn is the imperative segment of an economy's development ${ }^{24}$.

Turning to the quality of labour in rural markets of Pakistan, the market is constituted through unskilled labour with little or no education and training. Furthermore, the majority of the rural population (both males and females) faces seasonal unemployment in farm sector which is due to weather jeopardizes and price volatility. This further tends to upset the overall demand and supply of labour in rural economy ${ }^{25}$. Thus, these fluctuations in labour productivity and labour demand throughout the farm cycle cause seasonal migration and seasonal employment patterns ${ }^{26}$. Additionally, unskilled labour is another prominent feature of the rural clusters that restricts its contribution in the formal sector. Consequently, they are less paid than those employed in the formal sector $^{27}$.

Thus, these deficiencies of the labour market in rural economy of Pakistan have always remained a challenge in provision of productive and decent employment in rural areas. These impediments have also accelerated the unrecognized and poor-quality jobs with scarcity of social security ${ }^{28}$. These evidences from the rural economy of Pakistan have motivated to initiate this study to observe the employment trends in rural economy and to test and link up these trends with the transition of the rural economy in Pakistan.

\section{Objectives of the Study}

The main objective of this study is to provide an evidence of the transition in rural economy over three decades during 1987-88 to 2017-18 considering the employment perspective in Pakistan. This study provides rural-urban disparities (if exists) in labour force and determines the transition with the help of published data and computations to dig out the movement of labour from farm to non-farms sectors during given time period. Therefore, the study first elucidates the population dividend and migration patterns of the rural and urban economies of Pakistan. Later, the study observes the

${ }^{23}$ Spielman, David J., Sohail J. Malik, Paul Dorosh, and Nuzhat Ahmad, eds. Agriculture and the Rural Economy in Pakistan: Issues, Outlooks, and Policy Priorities. (University of Pennsylvania Press, 2016).

${ }^{24}$ Ghuman, Ranjit Singh. "Rural Non-farm Employment Scenario: Reflections from Recent Data in Punjab." Economic and Political Weekly (2005): 4473-4480.

${ }^{25}$ Ito, Takahiro, and Takashi Kurosaki. Weather Risk and the Off-Farm Labor Supply of Agricultural Households in India. No. 1004-2016-78657. 2006. https://core.ac.uk/download/pdf/6653459.pdf

${ }^{26}$ Sapkota, Kanhaiya. "Seasonal Labour Migration and Livelihood in the Middle Hill of Nepal: Reflections from Arghakhanchi District.” Research Nepal Journal of Development Studies 1, no. 1 (2018): 42-57.

${ }^{27}$ Afzal, Muhammad. "Structural Transformation, Openness and Economic Growth in Pakistan: Causality Analyses." Forman Journal of Economic Studies 3 (2007): 45-56.

${ }^{28}$ Policy, Social. "Development Centre (2013) The State of Social Development in Rural Pakistan." Social Development in Pakistan. Annual Review (2012). 
structure and composition of the labour market in rural economy. Meanwhile, the transition of the labour in rural economy will be analyzed through the sectoral compositions of rural and urban clusters based on percentage change computations.

\section{Research Hypotheses of the Study}

The rest of the study has been organized to figure out following research hypotheses;

- There is no change in rural-urban dividend and migration in rural economy.

- There is no shifting of labour force and employment opportunities in rural economy.

- There is no evidence of transition in rural economy from farm to non-farm sectors.

\section{Literature Review}

The discussion in the introduction section has delineated the fact that structural transformation has changed the structure of the economy in terms of both income and employment specifically in developing economies. This change in the composition of the aggregate factors has also modified the microeconomic indicators. Hence, this could be the reason that literature on rural transition is well grounded relating divergent aspects. Therefore, this section provides a brief view of some allied yet pertinent factors explaining the divergences generated due to transition in rural economy.

Initiating with the employment prospects of rural workers, Chand et al. ${ }^{29}$ qualitatively analyzed the change in rural India over the decades considering the time period of 19712012. The study indulged the job-led growth perspective and concluded that high reliance on farm sector and low remunerations were forcing the workers towards the non-farm sectors. The study also explored the rural-urban disparity in terms of labour productivity exhibited significant variations in the farm sectors (manufacturing and construction). Relating the structural change with employment, Venkatesh ${ }^{30}$ examined different facets of the rural economy in India. The author observed trends in rural employment, wages, agricultural growth, productivity; and rural non-farm employment and found a shift of rural employment from farm to non-farm sectors. The distinction was prominent in male workers with higher rate of transition in the decade of 2000. Despite this, the study revealed that wage growth in farm sector was higher than the non-farm sector showing better prospects for labour in the farm sector. Hence, the study stressed on a well mix employment policy for both farm and non-farm sectors of rural economy. Besides, Behera and Tiwari ${ }^{31}$ mulled empirical confirmation of trends in employment of farm and non-farm sectors in India whereas, for the same economy

\footnotetext{
${ }^{29}$ Chand, Ramesh, S. K. Srivastava, and Jaspal Singh. "Changes in Rural Economy of India, 1971 to 2012." Economic \& Political Weekly 52, no. 52 (2017): 65.

${ }^{30}$ Venkatesh, P. "Recent Trends in Rural Employment and Wages un India: Has the Growth Benefitted the Agricultural Labours?” Agricultural Economics Research Review 26, no. 347-2016-17099 (2013): 13-20.

${ }^{31}$ Behera, Deepak Kumar, and Mitali Tiwari. "Structural Transformation in India: An Econometric Investigation." Italian Economic J 56, no. 1 (2015): 1-18.
} 
Ghuman ${ }^{32}$ et al. and Gill et al. ${ }^{33}$ endeavored to capture the shift of rural labour from farm to non-farm occupations.

Lindberg ${ }^{34}$ observed the transition in rural economy in accordance with the growth of non-farm sector and state intrusions in India given the time period of 1969-1999. The author affirmed that Indian rural economy was experiencing slow yet stable income growth in the non-farm sector showing the equal significance same as farm sector. The study also attributed the growth of the non-farm activities with less poverty rates in rural areas. Hence, firmness in the dispersal of income was highly required given the issues of inequality, land ownership and operational area. The author declared that rural economy had been undergoing a change with its own peculiar features that were much different from earlier rural transformations of other global economies.

Considering the national perspective, Hamid ${ }^{35}$ empirically explored the contribution of major factors of the farm sector employing the Index approach. The findings of the study revealed an insignificant contribution of capital while labour productivity was found stumpy and declining given the time period of 1973-2007. On the whole, the study concluded that being a mainstay sector, the farm sector was not facilitating the economy of Pakistan. This economic deterioration of the farm sector could be attributed to inadequate initiatives of government for development of infrastructure and training of skilled labour. Gill ${ }^{36}$ evaluated the rural development initiatives in Pakistan and concluded that the main reason for failure of government policies were lack of divergence in the rural economy. The authors attributed the failure to the formation and implementation; and slow pace of rural development (human capital and infrastructure). The study suggested developing a conjoint working environment for farm and non-farm sectors in order to pave the way for more employment opportunities for rural masses.

The apparent phenomenon of migration is normally discussed as prime factor for the switch of labour from rural to urban clusters. Ozturk et al. ${ }^{37}$ discussed the affiliation between recent migration for employment and overall rural-urban mobilities in Turkey. The authors declared that employment, migration, city settlements and dual or counter migration (rural to urban and then urban-rural) were the key factors for decline in the rural population. Additionally, these aspects were reshaping the recent and emergent structures changing the demographic patterns and functions of the rural economy.

32 Ghuman, Ranjit Singh. "Rural Non-farm Employment Scenario: Reflections from Recent Data in Punjab." Economic and Political Weekly (2005): 4473-4480.

${ }^{33}$ Gill, Sucha Singh, and Ranjit Singh Ghuman. "Changing Agrarian Relations in India: Some Reflections from Recent Data." The Indian Journal of Labour Economics 44, no. 4 (2001): 809-26.

${ }^{34}$ Lindberg, Staffan. "Rural India 1970-2005: An Arduous Transition to What?." The Indian Journal of Labour Economics 55, no. 1 (2012): 61-75.

${ }^{35} \mathrm{Hamid}$, Abdul, and Hafiz Khalil Ahmad. "Growth and Productivity in Purview of Transitional Dynamics in Pakistan Agriculture Sector.” Pakistan Economic and Social Review (2009): 49-78.

${ }^{36}$ Gill, Zulfiqar Ahmad, Khalid Mustafa, and Waqar Ahmad Jehangir. "Rural Development in the $21^{\text {st }}$ Century: Some Issues." Pakistan Development Review 38, no. 4; Part 2 (1999): 1177-1187.

37 Öztürk, Murat, Beşir Topaloğlu, Andy Hilton, and Joost Jongerden. "Rural-Urban Mobilities in Turkey: Socio-spatial Perspectives on Migration and Return Movements." Journal of Balkan and Near Eastern Studies 20, no. 5 (2018): 513-530. 
Mukhtar et al. ${ }^{38}$ examined rural-urban migration in order to observe its impact in improving work quality and household well-being of rural migrants in the context of Pakistan. For empirical purposes, the study incorporated the Instrumental Probit and Two-step Sequential Estimation methods employing the primary data from main districts of four cities of Punjab province. The study provided an evidence that rural migrants were in better position in terms of remunerations and life style showing and overall improvement in household welfare. Ajaero and Onokala ${ }^{39}$ incorporated the rural -urban migration in the context of rural population employing Hierarchical cluster and Multiple Regression analyses. Using the mixed methodology, the study included questionnaire and interviews from six rural local management zones. The analysis showed that rural-urban migration contributed through monetary remittances. Hence, the authors stressed on the need of skill enhancement center in rural areas to improve the quality of life and employment opportunities in order to stanch rural -urban swaps. Additionally, Malik ${ }^{40}$ and $\mathrm{Khan}^{41}$ et al. also observed the outcomes of migration in lieu of employment and transformation in rural economy.

Keeping in view the wider perspective of rural transition, Jazic and $\mathrm{Joncic}^{42}$ related transition, liberalization and decentralization in Hungary. Moreover, the authors assessed the impact of these phenomenon on farm areas and rural economy. The study pointed that structural change in the economy had induced the market liberalization and decentralization due to enhancement in privatization. This in turn weakened the survival power of agricultural farms in the market. Further, liberalization also deteriorated the growth of the farm sectors in rural clusters. However, the author proposed that inclusion of Hungary in the European Union (EU) would stabilize farm sectors and rural economies given the effective measures as per the criteria of EU. Whereas, FreguinGresh $^{43}$ detected the nexus between structural change and rural transition to get an insight from developing economies experiencing globalization. Reardon ${ }^{44}$ also magnified the significance of rural non-farm employment through the lens of globalization in developing economies

The other ample perception in rural transition literature is linking social characteristics through employment swaps. Chaudhry, Malik and Ashraf ${ }^{45}$ investigated the related

${ }^{38}$ Mukhtar, Umar, Zhangbao Zhong, Beihai Tian, Amar Razzaq, Muhammad Naseer, and Tayyaba Hina. "Does Rural-Urban Migration Improve Employment Quality and Household Welfare? Evidence from Pakistan", Sustainability 10, no. 11 (2018): 4281.

${ }^{39}$ Ajaero, Chukwuedozie K., and Patience C. Onokala. "The Effects of Rural-Urban Migration on Rural Communities of Southeastern Nigeria.” International Journal of Population Research, (2013).

${ }^{40}$ Malik, Sohail Jehangir, Asjad Tariq Sheikh, and Amir Hamza Jilani. "Inclusive Agricultural Growth in Pakistan-Understanding Some Basic Constraints." Pakistan Development Review 55, no. 4 (2016): 889-903.

${ }^{41}$ Khan, Ayesha, and Adnan A. Khan. "Rural to Urban Migration: Connecting Opportunities, Addressing Gaps and Harnessing the Potential of Urbanisation." AHK Resource Centre. Karachi(2016).

42 Jazić, Aleksandar, and Miloš Jončić. "The Impact of Transition on Agriculture and Rural Areas in Hungary." Economics of Agriculture 64, no. 3 (2017): 1133-1145.

${ }^{43}$ Freguin-Gresh, Sandrine, Eric Thomas White, and Bruno Losch. "Rural Transformation and Structural Change: Insights from Developing Countries Facing Globalization.” IFSA, 2012.

${ }^{44}$ Reardon, Thomas, Kostas Stamoulis, and Prabhu Pingali. "Rural Nonfarm Employment in Developing Countries in an Era of Globalization." Agricultural Economics 37 (2007): 173-183.

${ }^{45}$ Chaudhry, Imran Sharif, Shahnawaz Malik, and Muhammad Ashraf. "Rural Poverty in Pakistan", Pakistan Economic and Social Review 44, no. 2 (2006): 259-276. 
insights and impediments of rural poverty in the context of farm sector of Pakistan. The empirical analysis of the study highlighted that rural clusters were the major poverty reservoir in Pakistan during the period of 1963-1999. Further, rural economy lags behind in terms of creating more employment opportunities in the non-f arm sector showing high reliance on the farm-sector and more poverty. Thus, the authors suggested elimination of poverty through enhancement in jobs (both farm and non-farm), investment, and entrepreneurship for sustainable living in the farm economy. In addition to this, Davis ${ }^{46}$ elucidated that education, infrastructure, capital accessibility, market exposures and business opportunities for Micro and small entrepreneurs were the essential factors responsible for the growth of non-farm rural economies specifically in transition countries. In this regard, the author stressed on significance of these factors focusing the heterogeneity of the non-farm economy in policy making. Foster ${ }^{47}$ examined the potential of rural areas through sector-specific yield, credit markets, human capital; and infrastructure for stable and well-paid employment in rural economy of low income countries. He particularly emphasized on enhancing the collaboration of both farm and non-farm sectors of the rural economy through regional and local product markets. Kaur et al. ${ }^{48}$ explored employment prospects and their association with welfare in rural clusters.

On the whole, the literature review provides extensive implications to observe the transition in rural economy at both national and international level. However, it is pertinent to mention here that at national level the transition of labour from farm to nonfarm sector has not been explored properly. This provides and intuition to perform this analysis for better understanding of the ongoing phenomenon and change in the rural economy of Pakistan.

\section{Methodology}

The study is qualitative in nature and hence the secondary has been utilized to perform a descriptive analysis. It is pertinent to mention here that the data has been grouped from authentic and reliable resources in order to ensure the appropriateness in the analysis.

\section{Data Sources}

The published data has been taken from government sources. These include Ministry of Finance $^{49}$, State Bank of Pakistan ${ }^{50}$ and Pakistan Bureau of Statistics ${ }^{51}$. The data has been gathered from various issues during the period of 1980- 2018.

${ }^{46}$ Davis, Junior. "Conceptual Issues in Analysing the Rural Non-Farm Economy in Transition Economies." (2001).

${ }^{47}$ Foster, Andrew D. "Creating Good Employment Opportunities for the Rural Sector." ADB Economics Working Paper Series 271 (2011).

${ }^{48}$ Kaur, Simrit, Vani S. Kulkarni, Raghav Gaiha, and Manoj K. Pandey. "Prospects of Non-farm Employment and Welfare in Rural Areas." 2010). Routledge Handbook of South Asian Economies (2010): 05.

${ }^{49}$ Ministry of Finance http://www.finance.gov.pk/

${ }^{50}$ SBP http://www.sbp.org.pk/

${ }^{51}$ PBS http://www.pbs.gov.pk/ 


\section{Analysis Findings \\ Population Dividend: Rural and Urban Trends}

Economic theory explain that structural transformation of the economy takes place when economic resources are shifted from low productive agriculture sector to high productive industry and service sectors. With the passage of time, population trends have shifted from rural to urban due to transition in the economy. Big cities and urban areas are the main major locations which provide benefits to migrated people while observing under-employed labour force from rural areas. Fastest economic growth is also related with the process of urbanization ${ }^{52}$.

Table 2: Rural and Urban Population Trends (1951-2017)

\begin{tabular}{|l|r|r|r|c|c|}
\hline Year & \multicolumn{3}{|c|}{ Population (Millions) } & \multicolumn{2}{c|}{ Population (percent) } \\
\hline & \multicolumn{1}{|c|}{ Total } & \multicolumn{1}{c|}{ Urban } & \multicolumn{1}{c|}{ Rural } & Urban & Rural \\
\hline 1951 & 33.81 & 6.01 & 27.79 & 17.79 & 82.19 \\
\hline 1961 & 42.97 & 9.65 & 33.32 & 22.46 & 77.53 \\
\hline 1981 & 84.25 & 23.84 & 60.41 & 28.29 & 71.70 \\
\hline 1991 & 112.61 & 34.66 & 77.95 & 30.77 & 69.22 \\
\hline 1995 & 124.49 & 29.54 & 94.95 & 23.72 & 76.27 \\
\hline 2001 & 142.86 & 47.50 & 95.36 & 33.24 & 66.75 \\
\hline 2005 & 156.04 & 53.92 & 102.12 & 34.55 & 65.44 \\
\hline 2011 & 177.10 & 66.37 & 110.73 & 37.47 & 62.52 \\
\hline 2015 & 191.71 & 75.19 & 116.52 & 39.22 & 60.77 \\
\hline 2016 & 195.41 & 77.93 & 117.48 & 39.88 & 60.11 \\
\hline 2017 & 207.98 & 75.80 & 132.18 & 36.44 & 63.55 \\
\hline Source: PES, 2019 & & & & & \\
\hline
\end{tabular}

Table explains the population trends in rural and urban regions. According to Pakistan Economic Survey ${ }^{53}$, the urban population is showing increasing trend with 36.3 percent of population in urban areas and 63.6 in rural areas. This indicates that movements from rural to urban clusters are mostly driven by economic and employment reasons. Moreover, it is also significant to bridge the gap between rural and urban population which potentially creates new opportunities for rural household ${ }^{54}$.

\footnotetext{
${ }^{52}$ Hussain, I. "Urbanization in Pakistan.” In Keynote Address Delivered at South Asia Cities Conference and Pakistan Urban Forum, vol. 9. 2014.

${ }^{53}$ Economic Survey of Pakistan, 2016-17. http://www.finance.gov.pk/

${ }^{54}$ Wiggins, Steve, Rachel Sabates-Wheeler, and Joseph Yaro. "Rural Transitions, Economies and Rural-Urban Links." (2018) https://opendocs.ids.ac.uk/opendocs/handle/123456789/13818
} 
Table 3: Population in Urban and Rural Areas

\begin{tabular}{|c|c|c|c|c|c|c|c|c|}
\hline \multirow[b]{3}{*}{$\begin{array}{l}\text { Density/ } \\
\text { Sq.km }\end{array}$} & \multicolumn{8}{|c|}{ Population (in thousands) } \\
\hline & \multicolumn{2}{|c|}{1972 CENSUS } & \multicolumn{2}{|c|}{1981 CENSUS } & \multicolumn{2}{|c|}{1998 CENSUS } & \multicolumn{2}{|c|}{2017 CENSUS } \\
\hline & Urban & Rural & Urban & Rural & Urban & Rural & Urban & Rural \\
\hline Islamabad & 77 & 161 & 204 & 136 & 529 & 276 & 1,014 & 992 \\
\hline Punjab & 9,183 & 28,424 & 13,052 & 34,241 & 23,019 & 50,602 & 40,387 & 69,625 \\
\hline Sindh & 5,726 & 8,430 & 8243 & 10,786 & 14,840 & 15,600 & 24,910 & 22,975 \\
\hline KPK & 1,196 & 7,193 & 1,665 & 9,396 & 2,994 & 14,750 & 5,730 & 24,793 \\
\hline Balochistan & 399 & 2,029 & 677 & 3,655 & 1,569 & 4,997 & 3,401 & 8,944 \\
\hline FATA & 13 & 2,478 & ------ & 2,199 & 85 & 3,091 & 142 & 4,860 \\
\hline Pakistan & 16,594 & 48,716 & 23,841 & 60,412 & 43,036 & 89,316 & 75,584 & 132,189 \\
\hline
\end{tabular}

Table 3 presents a brief expression of population in urban and rural areas from the four census in Pakistan. According to latest Census of 2017, Punjab is still the most populated province which consists of 40,387 thousands population in urban areas and 69,627 thousands in rural areas. Sindh remains the second largest populated province with 24,910 thousands in urban areas and 22975 thousands in rural areas. As far as Khyber Pakhtunkhwa (KPK) and Balochistan are concerned; the urban and rural populations have also significantly increased ${ }^{55}$.

Table 4: Province-wise Urban Rural Population Trends

\begin{tabular}{|l|r|r|r|r|r|r|}
\hline & \multicolumn{3}{|c|}{ Urban share (percent) } & \multicolumn{3}{c|}{ Rural share(percent)* } \\
\hline & $\mathbf{1 9 8 1}$ & $\mathbf{1 9 9 8}$ & $\mathbf{2 0 1 7}$ & $\mathbf{1 9 8 1}$ & $\mathbf{1 9 9 8}$ & $\mathbf{2 0 1 7}$ \\
\hline Pakistan & 28.3 & 32.52 & 36.38 & 71.7 & 67.48 & 63.62 \\
\hline KPK & 15.06 & 16.87 & 18.77 & 75.04 & 83.13 & 81.23 \\
\hline FATA & ---- & 2.69 & 2.84 & ---- & 97.31 & 97.16 \\
\hline Punjab & 27.6 & 31.27 & 36.71 & 72.40 & 68.73 & 63.29 \\
\hline Sindh & 43.32 & 48.75 & 52.02 & 56.68 & 51.25 & 47.98 \\
\hline Balochistan & 15.62 & 23.89 & 27.55 & 84.38 & 76.11 & 72.45 \\
\hline Islamabad & 60.06 & 65.72 & 52.58 & 39.94 & 34.28 & 47.42 \\
\hline
\end{tabular}

Source: PBS, 2019; Note: * Shows computation of Authors

Province-wise population trends in table 4points out the degree of urbanization which varies in each province. According to Census 2017, Sindh is the most urbanized province with 52.02 percent share of urban and 47.98 percent share of rural population. Although; Punjab is most populated province, the urban share of Punjab is yet36.71 percent along with 63.29 percent of rural population. Considering the province of KPK, 81.23 percent of population lives in rural areas whereas; in Balochistan, 72.45 percent of population lives in rural areas.

According to Mukhtar et al ${ }^{56}$ migration from rural to urban centers is a very common phenomenon in developing countries as developing economies experience structural

${ }^{55}$ Pakistan Economic Survey, 2017-18

${ }^{56}$ Mukhtar, et.al. Op.Cit. 
transformation from farm to non-farm sectors then people move to the urban areas. Moreover; fastest population growth is associated with rapid urbanization which creates fast urban population growth. It is evidently proved that size of population and migration seems to be positively correlated as people move from rural to urban areas because urban areas offer potentially higher income and better lifestyle. It also depends on migrant's productivity and skills, size of labor market, availability of human capital, diversity of employers; and mobility of labour ${ }^{57}$. Besides, there are many other factors that decide movement from rural to urban centres such as better education and health facilities.

Figure 2: Distribution of Rural to Urban Migration

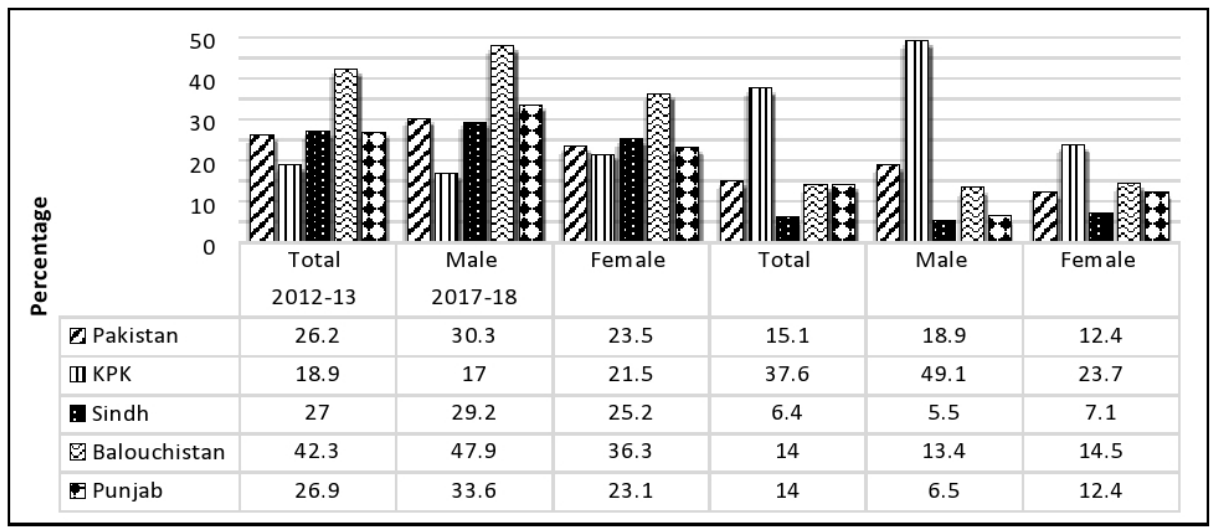

Source: Labour Force Survey (2012-13, 2017-18)

Contrary to traditional perspective, figure 1 shows a declining trend in rural to urban migration in all provinces except KPK during the comparative time period of 2012-13 to 2017-18. This shows that it is due to expansion of non-farm activities in rural areas ${ }^{58}$. The spreading out of non-farm activities in rural areas have also allowed to rural population to work near home ${ }^{59}$.

${ }^{57}$ Malik, Asma Seemi. "RURAL URBAN MIGRATION.” The Professional Medical Journal 22, no. 06 (2015): 674-682.

${ }^{58}$ Lanjouw, Jean O., and Peter Lanjouw. "The Rural Non - farm Sector: Issues and Evidence from Developing Countries." Agricultural Economics 26, no. 1 (2001): 1-23.

${ }^{59}$ Davis, Junior. "Conceptual Issues in Analysing The Rural Non-farm Economy in Transition Economies." (2001). https://pdfs.semanticscholar.org/e9ca/a6a38d46d084597c8669df32197647f43bda.pdf 
Figure 3: Migrants Employed by Employment Status (\%)

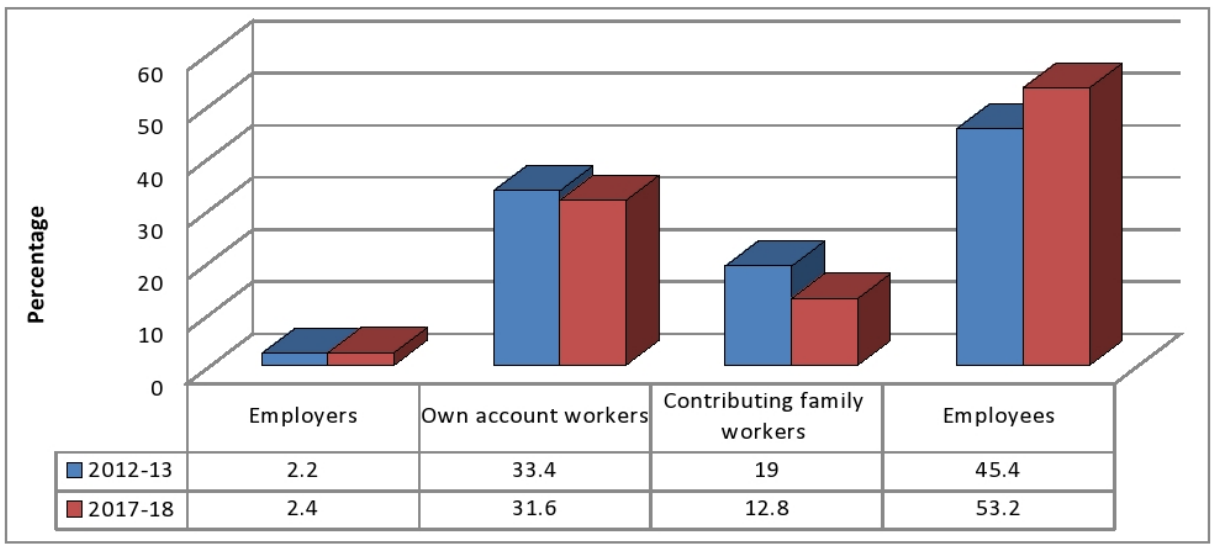

Source: Labour Force Survey (2012-13, 2017-18)

Figure 2 highlights the status of migrants during 2012-13 to 2017-18. Most of the migrants are employed as own account workers and as employees. However, it is evident that percentage of employee has increased from 45.4 to 53.2 percent whereas; own account workers has decreased from 33.4 percent to 31.6 percent during 2013-13 to 2017-18. On the other hand, the share of contributing family workers has also declined from 19 percent to 12.8 percent. So as for transition during given time period, the status of migrants as employee increased while other trends have gone down. There are many reasons behind decreasing trends in rural to urban migration such as economic opportunities are not created employment opportunities for rural population. Moreover, rural labour is considered as unskilled or low skilled labour therefore; they do not have enough employment opportunities in big cities. The role of rural labour in manufacturing and service sectors are limited due to non-availability of required education, skills and knowledge. Despite their hoping for better life style, many migrants from rural area find difficult that well-paying jobs are not easily available in the cities. Therefore; many specialized jobs are needed that could easily compensate these low skilled migrants in formal sectors ${ }^{60}$.

\section{Labour Market Structure and Composition of Rural Economy}

The analyses and discussions in the previous sections has clearly outlined the fact that rural areas have more population and meanwhile providing more employment opportunities with greater absorption of rural labour. This section first analyzes the structure and composition of the labour market over the years. The rural labour market

${ }^{60}$ Khan, Ayesha, and Adnan A. Khan. "Rural to Urban Migration: Connecting Opportunities, Addressing Gaps and Harnessing the Potential of Urbanisation." AHK Resource Centre. Karachi(2016). 
is experiencing substantial change due to increasing employment opportunities outside agriculture $^{61}$.

Table 5 : Civilian Labour Force of Pakistan and Provinces (Millions)

\begin{tabular}{|c|c|c|c|c|}
\hline Province/Area & $\mathbf{1 9 9 7 - 9 8}$ & $\mathbf{2 0 0 7 - 0 8}$ & $\mathbf{2 0 1 7 - 1 8}$ & $\begin{array}{c}\text { Estimated Change during 2007-08 \& } \\
\text { 2017-18 (percent) }\end{array}$ \\
\hline Pakistan & $\mathbf{3 8 . 1 9}$ & $\mathbf{5 1 . 7 8}$ & $\mathbf{6 5 . 5}$ & $\mathbf{2 6 . 4 9}$ \\
\hline Rural & 26.47 & 36.18 & 42.91 & 18.60 \\
\hline Urban & 11.02 & 15.60 & 22.59 & 44.80 \\
\hline Punjab & $\mathbf{2 4 . 4 6}$ & 30.67 & $\mathbf{3 9 . 3 0}$ & $\mathbf{2 8 . 1 3}$ \\
\hline Rural & 17.50 & 21.91 & 26.81 & 22.36 \\
\hline Urban & 6.96 & 8.76 & 13.17 & 50.34 \\
\hline Sindh & $\mathbf{7 . 9 7}$ & $\mathbf{1 2 . 6 5}$ & $\mathbf{1 5 . 1 9}$ & $\mathbf{2 0 . 0 7}$ \\
\hline Rural & 4.13 & 7.27 & 7.84 & 7.84 \\
\hline Urban & 3.84 & 5.38 & 7.35 & 36.61 \\
\hline KPK & $\mathbf{4 . 4 3}$ & $\mathbf{6 . 2 7}$ & $\mathbf{6 . 4 5}$ & $\mathbf{2 . 8 7}$ \\
\hline Rural & 3.71 & 5.27 & 5.19 & -1.518 \\
\hline Urban & 0.72 & 1.00 & 1.26 & 26.00 \\
\hline Balochistan & $\mathbf{1 . 3 3}$ & $\mathbf{2 . 1 9}$ & $\mathbf{2 . 3 7}$ & $\mathbf{8 . 2 1}$ \\
\hline Rural & 1.13 & 1.73 & 1.77 & 2.31 \\
\hline Urban & 0.20 & 0.46 & 0.60 & 30.43 \\
\hline
\end{tabular}

Note: the data for civilian labour force in million is not available for the year 1987-88

The employment structure of an economy is defined by its civilian labour force that includes both employed and unemployed persons. This precisely elaborates the availability and absorption of working age population in Pakistan and in its provinces as well. Table 5 explains the availability of labour in all provinces at both rural and urban locations. The table clearly depicts that there is still more civilian labour (employed and unemployed) in rural economy than urban areas throughout the period of 1997-2018. Furthermore, the provincial data reveals that Punjab and KPK predominantly continue to have more share of labour in its rural economy over the years. Considering the Punjab, it could be attributed to the fact that most of the population clusters exist in the province. Besides, rural areas of Punjab are more developed with better employment prospects for labour ${ }^{62}$. In KPK, there is relatively more unemployment in the province with low employment prospects ${ }^{63}$.

According to the recent $\mathrm{LFS}^{64}$, it has 7.16 percent of unemployment which is more than the unemployment rates of Punjab (5.97 percent), Sindh (4.92 percent) and Balochistan (4.09 percent).Furthermore, minor differences in the availability of labour force has been observed in rural and urban areas of Sindh and Balochistan. In the nutshell, at provincial level there are prominent differences in terms of labour availability, hence

${ }^{61}$ Chand, Ramesh, and S. K. Srivastava. "Changes in the Rural Labour Market and tImplications for Agriculture." Economic and Political Weekly 49, no. 10 (2014): 47-54

${ }^{62}$ Tasneem, Naila, "Assessment of Labor Market Dynamics in the Cities of Punjab: Implications for CPEC."

2018). https://www.pide.org.pk/psde/pdf/AGM34/papers/Naila-Tasneem.pdf

${ }^{63}$ Shah, Syed Akther Hussain, Tariq Shah, and Mahmood Khalid. Employment Strategy and Equitable Growth: A Social Capital Perspective for KPK. No. 2015: 120. (Pakistan Institute of Development Economics, 2015).

${ }^{64}$ Labour Force Survey, 2017-18 http://www.finance.gov.pk/ 
creating gaps and indicating that there would be divergences in the structure of the labour markets in the rural economies of Pakistan. The absorption of the labour market has been explained through the participation rate of labour in both rural and urban areas in table 6 .

Table 6: Labour Force Participation Rate in Rural and Urban Economies

\begin{tabular}{|c|c|c|c|c|c|}
\hline & $\mathbf{1 9 8 7 - 8 8}$ & $\mathbf{1 9 9 7 - 9 8}$ & $\mathbf{2 0 0 7 - 0 8}$ & $\mathbf{2 0 1 7 - 1 8}$ & $\begin{array}{c}\text { Estimated Change during } \\
\text { 2007-08\& 2017-18 (percent) }\end{array}$ \\
\hline Pakistan & $\mathbf{2 8 . 8 3}$ & $\mathbf{2 9 . 3 8}$ & $\mathbf{3 2 . 1 7}$ & $\mathbf{3 1 . 7 0}$ & -1.46 \\
\hline Rural & 29.9 & 30.58 & 33.84 & 32.71 & -3.33 \\
\hline Urban & 26.28 & 26.98 & 28.87 & 29.95 & 3.74 \\
\hline Punjab & $\mathbf{2 9 . 7 6}$ & $\mathbf{3 2 . 1 9}$ & $\mathbf{3 3 . 8 4}$ & $\mathbf{3 4 . 9 9}$ & 3.39 \\
\hline Rural & 30.77 & 33.59 & 35.54 & 37.30 & 4.95 \\
\hline Urban & 26.56 & 29.14 & 30.22 & 31.08 & 2.84 \\
\hline Sindh & $\mathbf{2 8 . 1 5}$ & $\mathbf{2 6 . 5}$ & $\mathbf{3 2 . 2 9}$ & $\mathbf{3 0 . 2 4}$ & -6.34 \\
\hline Rural & 30.63 & 28.46 & 36.6 & 30.52 & -16.61 \\
\hline Urban & 25.54 & 24.68 & 27.85 & 29.94 & 7.50 \\
\hline KPK & $\mathbf{2 5 . 7 9}$ & $\mathbf{2 3 . 6 9}$ & $\mathbf{2 6 . 9 5}$ & $\mathbf{2 4 . 3 8}$ & -9.53 \\
\hline Rural & 25.89 & 23.74 & 27.11 & 24.23 & -10.62 \\
\hline Urban & 29.3 & 23.41 & 26.12 & 25.07 & -4.01 \\
\hline Balochistan & $\mathbf{2 8 . 6 8}$ & $\mathbf{2 5 . 4 6}$ & $\mathbf{2 7 . 8 2}$ & $\mathbf{2 4 . 9 3}$ & -10.38 \\
\hline Rural & 29.38 & 26.25 & 29.01 & 25.66 & -11.54 \\
\hline Urban & 25.03 & 21.78 & 24.06 & 22.99 & -4.44 \\
\hline
\end{tabular}

Source: Compiled by Authors from various publication of LFS

Note: *shows computation of authors

The labour force participation rate indicates proportion of people in labour force and elaborates working capacity and job market trends. Table 6 explains the absorption of employed workers at provincial level through labour market participation rates. It is pertinent to mention here that rural areas in all provinces have more absorption of labour than the urban economies given time period. The comparison of rural and urban labour participation rate affirms that labor participation is higher in rural areas as compared to urban areas at both provincial and country level. However; during given time period, labour participation has increased in rural Punjab whereas; it has declined in remaining provinces which shows that there is more employment absorption in rural areas of Punjab. This is quiet convincing as Punjab is more developed and expanding while providing better employment opportunities and wages as compare to other provinces.

\section{Employment Composition of Rural Economy: Sectoral Perspective}

The employment composition of the rural economy in this section has been analyzed through observing the sectoral compositions (farm and non-farm) of rural economy. In this regard, we will first analyze the sectoral compositions of the farm and non-farm sectors at provincial level in table 7. Then, the rural and urban compositions of workers at sectoral level will be analyzed through table 8 in the respective sectors. 
Table 7: Province-wise Composition of Employed Persons in Farm and Non-farm Sectors

\begin{tabular}{|c|c|c|c|c|c|}
\hline & $\mathbf{1 9 8 7 - 8 8}$ & $\mathbf{1 9 9 7 - 9 8}$ & $\mathbf{2 0 0 7 - 0 8}$ & $\mathbf{2 0 1 7 - 1 8}$ & $\begin{array}{c}\text { Estimated Change during } \\
\text { 2007-08 to 2017-18 } \\
\text { (percent) }\end{array}$ \\
\hline Pakistan & & & & & \\
\hline Farm Sector & 51.15 & 47.25 & 44.6 & 38.5 & -13.67 \\
\hline Non-Farm Sector & 48.84 & 52.75 & 55.4 & 61.5 & 11.01 \\
\hline Punjab & & & & & -7.89 \\
\hline Farm Sector & 51.50 & 57.75 & 43.44 & 40.01 & 6.06 \\
\hline Non-Farm Sector & 45.5 & 42.25 & 56.56 & 59.99 & -19.33 \\
\hline Sindh & & & & & 16.55 \\
\hline Farm Sector & 47.41 & 43.12 & 46.13 & 37.21 & \\
\hline Non-Farm Sector & 52.59 & 528.88 & 53.87 & 62.79 & -26.85 \\
\hline KPK & & & & & 21.62 \\
\hline Farm Sector & 59.37 & 48.28 & 44.6 & 32.62 & \\
\hline Non-Farm Sector & 40.62 & 51.72 & 55.4 & 67.38 & -24.04 \\
\hline Balochistan & & & & & 26.78 \\
\hline Farm Sector & 66.51 & 57.75 & 52.7 & 40.03 & \\
\hline Non-Farm Sector & 33.49 & 42.25 & 47.3 & 59.97 & \\
\hline
\end{tabular}

Source: Various Issues of LFS; Note: * computations of Authors

The table reveals that there is a quantum shift of labour from farm to non-farm sector during the span of 1987-2018. This trend has raised striking features of the rural economy of Pakistan as 13.67 percent of change has been observed during the last decade which shows a big shift in the overall workforce to non-farm activities (11.01 percent). Turning to the farm sector of the provinces, KPK stands out with greater shift away from farm activities towards non-farm sector. Punjab showed a little deviation yet it has also experienced a decline of 7.98 percent in farm employment while its non-farm employment share has been increased up to 6.06 percent. This negative trend has been observed in all provinces.

Considering the sectoral compositions of rural and urban economies at provincial level, there was a slow movement of labour towards the non-farm activities in Punjab, yet there were relatively more employed persons in the farm sector than other provinces. Being an agrarian province with more farming activities the province has managed to maintain a reasonable balance between the two sectors. According to the Punjab Economic report ${ }^{65}$, this is due to the fact that over the years, Punjab has maintained to provide more employment opportunities due to the obvious demographic dividend. The report claims that there were more than 35 percent of total population in Punjab belonged to the young age cohort (15-34) while 60.07 percent was related to the working age cohort (15-64). Hence, the authorities were engaged in providing better opportunities and taking practical steps to engage the youth productively in the labor force through investment in education and skills training development programs ${ }^{66}$.

${ }^{65}$ Punjab Economic Research Institution (PERI). Punjab Economic Report (2017). https://peri.punjab.gov.pk/ ${ }^{66}$ Tasneem, Naila, "Assessment of Labor Market Dynamics in the Cities of Punjab: Implications for CPEC." 2018). https://www.pide.org.pk/psde/pdf/AGM34/papers/Naila-Tasneem.pdf 
Although the province of Balochistan also follows the same scenario, yet the reasons behind this are well differentiated. Additionally, Sindh and KPK were expectedly relying more on non-farm activities due to its geographical structure and relatively more urbanized areas and migration.

\section{Transition in Employment of Rural Economy}

The analysis of structure and composition of the labour market in rural economy has clearly outlined the fact that there is prominent shift of labour from farm to non-farm sectors at both country and provincial level. This provides an indication to move on to the actual transition of the rural economy in employment through analyzing the shares of farm and non-farm sectors. Meanwhile, this section also represents an insight of formal and informal activities of the rural and urban economy. The transition of the rural economy through employment patterns has been presented in table 8 . The table provides the rural and urban distribution of employed persons in both farm and nonfarm sectors. It is pertinent to mention here that these sectoral shares have been computed through combining the shares of farm and various non-farm sectors.

Table 8: Transition in Employment of Rural Economy (Farm and Non-Farm Sector)

\begin{tabular}{|c|c|c|c|c|c|c|c|c|}
\hline & \multicolumn{4}{|c|}{ Rural } & \multicolumn{4}{|c|}{ Urban } \\
\hline & $\begin{array}{l}1997- \\
98 \\
\end{array}$ & $\begin{array}{l}2007- \\
08 \\
\end{array}$ & $\begin{array}{l}2017- \\
18 \\
\end{array}$ & $\begin{array}{c}\text { Estimated change } \\
\text { during 2007-08 } \\
\& 2017-18 \\
\text { (percent) } \\
\end{array}$ & $\begin{array}{l}1997- \\
98 \\
\end{array}$ & $\begin{array}{l}2007- \\
08 \\
\end{array}$ & $\begin{array}{l}2017- \\
18 \\
\end{array}$ & $\begin{array}{l}\text { Estimated change } \\
\text { during } 2007-08 \& \\
2017-18 \text { (percent) }\end{array}$ \\
\hline \multicolumn{9}{|l|}{ Punjab } \\
\hline Farm Sector & 46.31 & 41.66 & 38.18 & -8.35 & 1.57 & 1.78 & 1.84 & 13.3 \\
\hline $\begin{array}{l}\text { Non-Farm } \\
\text { Sector }\end{array}$ & 26.37 & 30.27 & 29.31 & -3.17 & 25.76 & 26.29 & 30.68 & 2.05 \\
\hline \multicolumn{9}{|l|}{ Sindh } \\
\hline Farm Sector & 40.99 & 43.84 & 34.43 & -21.46 & 2.13 & 2.29 & 2.74 & 7.5 \\
\hline $\begin{array}{l}\text { Non-Farm } \\
\text { Sector }\end{array}$ & 11.25 & 14.94 & 18.36 & 22.89 & 45.67 & 39.61 & 44.43 & -13.2 \\
\hline \multicolumn{9}{|l|}{ KPK } \\
\hline Farm Sector & 46.79 & 43.51 & 31.32 & -28.012 & 1.49 & 1.09 & 3.66 & -26.84 \\
\hline $\begin{array}{l}\text { Non-Farm } \\
\text { Sector } \\
\end{array}$ & 37.11 & 40.67 & 50.42 & 23.97 & 14.56 & 14.72 & 21.01 & 1.09 \\
\hline \multicolumn{9}{|l|}{ Balochistan } \\
\hline Farm Sector & 56.38 & 50.43 & 36.43 & -27.762 & 1.37 & 2.26 & 1.36 & 64.96 \\
\hline $\begin{array}{l}\text { Non-Farm } \\
\text { Sector }\end{array}$ & 28.84 & 29.32 & 38.96 & 32.87 & 13.43 & 17.99 & 16.9 & 33.95 \\
\hline
\end{tabular}

Source: LFS (1987-88, 1997-98, 2007-08, 2017-18); Note: Computed by Authors

The declining trend from farm to non-farm confirms the transition in rural economy through employment changes in all provinces. This affirms that the transition of rural economy has been changing along with overall economy. The farm and non-farm sectors have also been changing its structure through diversification of activities. It has become crucial to examine the transition of rural economy in terms of farm to non-farm activities change. The extent to which the rural farm and non-farm activities have 
undergone any transformation is a matter of policy concern ${ }^{67}$. This could be attributed to various supply-side and demand-side gaps creating structural problems in the labour market system ${ }^{68}$. The supply-side gaps include lack of certification, lack of appropriate skills and knowledge, communication gaps, lack of marketing skills; and technological backwardness etc. while demand-side gaps include employer related gaps, lack of formal system of knowledge, public-private disconnect; and credibility etc. The estimates based on data, portray a remarkable transformation in employment of rural economy of Pakistan during the decades of 1990s, and 2000s. This is partly due to the fact that uncertainties in employment of the farm economy have pushed workers out of agricultural sector to move in to non-farm sectors showing the pull capacity of the sector to absorb the disguised employed and redundant/surplus workers of the farm sector ${ }^{6970}$. The transition of labour market is also dependent on formal and informal distribution of the labour market specifically in rural areas. Hence, the study analysis also demands to evaluate the informality of the sector as it is the major issue of the rural economy and meanwhile provides the dynamism to the non-farm employment ${ }^{71}$.

Table 9: Distribution of Employed Persons in Formal and Informal Sectors (Non-Farm)

\begin{tabular}{|c|c|c|c|c|c|c|c|c|}
\hline & \multicolumn{4}{|c|}{ Rural Areas } & \multicolumn{4}{|c|}{ Urban Areas } \\
\hline & 1997-98 & 2007-08 & 2017-18 & $\begin{array}{l}\text { Percent } \\
\text { change }\end{array}$ & $1997-98$ & $2007-08$ & 2017-18 & $\begin{array}{l}\text { percent } \\
\text { change }\end{array}$ \\
\hline \multicolumn{9}{|l|}{ Pakistan } \\
\hline Formal & 6.56 & 6.83 & 7.12 & 4.245 & 10.41 & 8.22 & 10.11 & 22.9 \\
\hline Informal & 17.84 & 20.61 & 22.48 & 9.073 & 17.93 & 19.69 & 31.8 & 61.5 \\
\hline \multicolumn{9}{|l|}{ Punjab } \\
\hline Formal & 3,87 & 6.5 & 7.6 & 16.92 & 5.15 & 6.63 & 9.01 & 35.8 \\
\hline Informal & 12.92 & 23.72 & 22.61 & -4.679 & 11.25 & 19.66 & 21.68 & 10.2 \\
\hline \multicolumn{9}{|l|}{ Sindh } \\
\hline Formal & 1.07 & 4.49 & 5.43 & 20.93 & 4.42 & 14.15 & 16.37 & 15.6 \\
\hline Informal & 1.34 & 9.76 & 12.93 & 32.4 & 5.41 & 25.46 & 28.02 & 10.0 \\
\hline \multicolumn{9}{|l|}{ KPK } \\
\hline Formal & 1.24 & 10.94 & 10.7 & -2.198 & 0.63 & 3.84 & 4.35 & 13.2 \\
\hline Informal & 2.92 & 29.73 & 39.78 & 33.8 & 1.00 & 10.88 & 12.55 & 15.3 \\
\hline \multicolumn{9}{|l|}{ Balochistan } \\
\hline Formal & 0.38 & 13.78 & 12.85 & -6.74 & 0.21 & 7.49 & 7.02 & -6.2 \\
\hline Informal & 0.66 & 15.54 & 26.11 & 68.0 & 0.27 & 10.5 & 13.99 & 33.2 \\
\hline
\end{tabular}

${ }^{67}$ Pal, Dipti Prakas, and Mausumi Datta Biswas. "Diversification of Farm aNon-farm Sectors and Structural Transformation of Rural Economy." In $19^{\text {th }}$ International Input Output Conference, University of Kalyani, Kalyani, India, p. 1. 2009.

68 Shah, Syed Akther Hussain, Tariq Shah, and Mahmood Khalid. Employment Strategy and Equitable Growth: A Social Capital Perspective for KPK. No. 2015: 120. (Pakistan Institute of Development Economics, 2015).

${ }^{69}$ Behera, Deepak Kumar, and Mitali Tiwari. "Structural Transformation in India: An Econometric Investigation." Italian Economic J 56, no. 1 (2015): 1-18.

${ }^{70}$ Gill, Sucha Singh, and Ranjit Singh Ghuman. "Changing Agrarian Relations in India: Some Reflections from Recent Data." The Indian Journal of Labour Economics 44, no. 4 (2001): 809-26.

${ }^{71}$ Davis, Junior. "Conceptual Issues in Analysing the Rural Non-farm Economy in Transition Economies." (2001). https://pdfs.semanticscholar.org/e9ca/a6a38d46d084597c8669df32197647f43bda.pdf 
Table 9 describes that the large informal sector in Pakistan is operating parallel with formal sector and almost 72.6 percent of non-farm labour has been absorbed in the sector. With the passage of time non-farm activities were expanded in rural areas however; employment has been generated only in informal sector. At provincial level, informal sectors of KPK and Balochistan are prominent in engaging largest number of rural labour (39.78 percent and 26.11percent respectively) showing labour exploitation as compared to formal sector.

\section{Factors of Transition of Rural Economy from Farm to Non-Farm Sector}

The previous section explains clear pattern of transition of labour from rural farm sector to non-farm sector. Here, a question arises that what are the relevant factors that transferred the labour of farm sector towards non-farm sector. Intuitively, factors of underemployment, unpaid work, and seasonal employment tend to produce huge instabilities in employment patterns of the rural economy. However, here we have outlined two major factors that provide an inducement for rural households to diversify into non-farm employment. These can be classified as "Push Incentives" and "Pull Incentives". It is pertinent to mention here that these incentives are contemplated only for transition of labour within the rural economy from farm to non-farm sector.

Considering the former incentives, it is already explored in first section that employment growth of the farm sector has been persistently decreasing which is meanwhile not in consonance with the overall growth of the economy due to subsistence farming ${ }^{72}$. Furthermore, not surprisingly, the agriculture sector of developing economy alone does not have the potential to sustain the expansion of rural economies ${ }^{73}$, which seems convincing for Pakistan as well. Besides, the non-farm sector provides more income diversification than farm sector in Pakistan that points out the high productivity specifically in informal services sector ${ }^{74}$. Mukhtar et al. ${ }^{75}$ also pointed that exogenous shocks such as rainfall and droughts were also responsible to diverge the labour from the farm sector in Pakistan. Consequently, these stylized facts are thus responsible for pushing the labour to persistently diversify their activities towards the non-farm sector.

Turning to the later incentives, there is a list of capacity parameters that may pull farm labour of rural economy to move into non-farm sector. These pull factors of the nonfarm sector in rural economy may include the development in human capital through better education arrangements, access to financial credit, organizational expertise and improvement in social pattern ${ }^{76}$. Looking at the overall rural economy of Pakistan, the economy has yet not achieved its true potential due to the fact that condition of human capital and education system in rural areas is yet not up to the mark.

${ }^{72}$ Malik, Sohail Jehangir, Asjad Tariq Sheikh, and Amir Hamza Jilani. "Inclusive Agricultural Growth in Pakistan-Understanding Some Basic Constraints.” Pakistan Development Review 55, no. 4 (2016): 889-903.

${ }^{73}$ Hazell, Peter. "Is Small Farm Led Development Still a Relevant Strategy for Africa and Asia." (2013). www.fondationfarm.org/zoe/doc/farm_pointdevue_201309_phazell_en.pdf

${ }^{74}$ Muhammad, Tahir, H. Khan, and A. Qahar. "Factors Determining Off-farm Employment on Small Farms in District Nowshehra of North West Pakistan." Sarhad Journal of Agriculture 28, no. 2 (2012): 333-343.

${ }^{75}$ Mukhtar, et.al. Op.Cit.

${ }^{76}$ Ghuman, Ranjit Singh. "Rural Non-farm Employment Scenario: Reflections from Recent Data in Punjab." Economic and Political Weekly (2005): 4473-4480. 
According to the Pakistan National Human Development Report ${ }^{77}$, the human development in Pakistan still requires an improvement in education and employment of rural areas. The report explained that the literacy rate of 10 years and above was still 25 percent lower in rural areas than the urban parts. Meanwhile, the youth also face barriers in access to technical and vocational skills. This could be the reason that most of the non-farm employed persons are absorbed in the informal segment of the non-farm economy. Additionally, inefficiencies of financial institutions still restrict rural households to access the credit $^{78}$ while the process of organizational expertise is although rapidly increasing yet it is in its stage of infancy in rural areas. Meanwhile, industrialization of the rural economy is also missing due to lack of institutional support from government.

On the whole, despite the prominent development in infrastructure, push incentives of the farm sector are stronger than the pull incentives for the movement of labour away from the farm sector to non-farm sector in Pakistan. This argument is in line with the study of Behera and Tiwari ${ }^{79}$. The authors explained that growth pattern of developing economies follow a movement of labour to the non-farm sector due to sufficient and precarious pull effect. The evidence of the compiled data and computations of change show that the distribution of employment has been persistently changing and moving towards the non-farm sector at both provincial and country level.

\section{Conclusion and Policy Recommendations}

This study attempts to observe the transition in rural economy considering labour market composition and employment in Pakistan. We have found evidence of transition in the rural economy which points out a surge in share of employment in non-farm sector endorsing the alternate hypotheses of the study. Furthermore, the study has also explored major deviations at provincial level. The study concludes that structural transformation in Pakistan has also altered the labour market structure and composition of the rural economy. In consonance with these outcomes, the study also stresses on the major concern of rural development through achieving inclusive growth with an increase in per capita income and productivity enhancement for both farm and non-farm sectors.

An immense focus is required for employment in agriculture sector while creating more diversification in agricultural activities. There is also a dire need to enhance occupational activities such as agro-based processing, new farming practices, livestock, small scale manufacturing, retail trade, construction etc. This will not only diversify the occupational structure but also enhance income of labour in rural areas. In this regard, a few doable policy implications have been prescribed;

77 Pakistan Human Development Report. Unleashing the Potential of a Young Pakistan, (2017)https://www.undp.org/content/dam/pakistan/docs/HDR/PK-NHDR.pdf

${ }^{78}$ Chandio, Abbas Ali, Habibullah Magsi, Abdul Rehman, and Jam Ghulam Murtaza Sahito. "Types, Sources and Importance of Agricultural Credits in Pakistan." Journal of Applied Environmental and Biological Sciences 7, no. 3 (2017): 144-149.

79 Behera, Deepak Kumar, and Mitali Tiwari. "Structural Transformation in India: An Econometric Investigation." Italian Economic J 56, no. 1 (2015): 1-18. 
- Given the constraints of rural economy, the farm expansion and enduring growth of the rural population require rising food production through efficient irrigation and innovation technology.

- The diversification in agricultural product such as higher value crops and livestock must be ensured through upgraded marketing and cold chains. This would definitely create more employment opportunities in the rural economy of Pakistan.

- The non- farm sector of the rural economy must keep up its pace in expanding labour force participation through providing support services of the farm sector. These include set ups of small and medium enterprises and agriculture support services in rural clusters,

- The farm sector also requires specialization in specific brand products through technology and improved land rental and marketing policies.

- An increase in process of mechanization and land consolidation would also enhance the off-farm jobs in rural clusters.

- An initiative of creating smart cities may integrate the diversified economies of rural and urban areas creating more employment prospects for both rural and urban labour. This may also tend to eliminate the wage gap between the offered wages to labour. .

- There is a massive need of development of physical infrastructure with a viewpoint of developing the social capital in rural areas. Such development thus requires the exploitation of entrepreneurial skills specifically for youth. This could not be done without improvement in the quality of human capital.

- The target of inclusive growth may conveniently be achieved through enhancing the employment potential for women in rural areas by providing them training and better assistance.

- There is a dire need of vertical integration of agricultural output with the nonfarm enterprises for the sustainability of agricultural sector, rural non- farm enterprises / activities and, of course, the entire rural economy.

It is high time for the provincial governments to develop their own development banks for the farm sector. This would foster the financial as well as technical support to farmers.

\section{Bibliography}

Behera, Deepak Kumar, and Mitali Tiwari. "Structural Transformation in India: An Econometric Investigation.” Italian Economic J 56, no. 1 (2015). 
Bhullar, Gurinder Jit Singh, and Harinder Mohan. "Ill effects of green revolution on the agricultural development in Punjab." Indian Journal of Economics and Development 11, no. 1 (2015).

Davis, Junior. "Conceptual issues in analyzing the rural non-farm economy in transition economies." (2001).

Ghuman, Ranjit Singh, and Parvinder Kaur Dua. "Employment Guarantee Scheme in Punjab A Case Study of Hoshiarpur District." Right to Work and Rural India: Working of the Mahatma Gandhi National Rural Employment Guarantee Scheme (MGNREGS) 169 (2012).

Gregori, Tullio, and R. O. B. E. R. T. O. Pietroforte. "Patterns of structural changes in construction?." In Management and Innovation for a Sustainable Built Environment MISBE 2011, Amsterdam, The Netherlands, June 20-23, 2011. CIB, Working Commissions W55, W65, W89, W112; ENHR and AESP, 2011.

Jayadevan, C. M. "A canonical correlation analysis of sectoral composition of GDP and development in Asia." Modern Economy 9, no. 2 (2018).

Malik, Sohail Jehangir, Asjad Tariq Sheikh, and Amir Hamza Jilani. "Inclusive Agricultural Growth in Pakistan-Understanding Some Basic Constraints." Pakistan Development Review 55, no. 4 (2016)

Nhavira, John DG. "Zimbabwe's prospects for transformation and growth." Journal of Strategic Studies: A Journal of the Southern Bureau of Strategic Studies Trust 8, no. 1 (2017). 